\title{
Determinants of survival in children with cancer in Johannesburg, South Africa
}

\begin{tabular}{|c|c|}
\hline \multicolumn{2}{|c|}{$\begin{array}{l}\text { Authors: } \\
\text { Nadia Beringer }{ }^{1,2} \\
\text { Kate G. Bennett }^{3} \\
\text { Janet E. Poole } \\
\text { Jennifer A. Geel } \\
\text { Jan }\end{array}$} \\
\hline \multicolumn{2}{|c|}{$\begin{array}{l}\text { Affiliations: } \\
\text { 'Department of Paediatrics } \\
\text { and Child Health, Faculty of } \\
\text { Health Sciences, School of } \\
\text { Clinical Medicine, University } \\
\text { of the Witwatersrand, } \\
\text { Johannesburg, South Africa }\end{array}$} \\
\hline \multicolumn{2}{|c|}{$\begin{array}{l}\text { 2Department of Paediatrics, } \\
\text { Division of Paediatric } \\
\text { Haematology and Oncology, } \\
\text { Johannesburg Hospital, } \\
\text { Johannesburg, South Africa }\end{array}$} \\
\hline \multicolumn{2}{|c|}{$\begin{array}{l}{ }^{3} \text { Department of Paediatric } \\
\text { Oncology, Wits University } \\
\text { Donald Gordon Medical Centre, } \\
\text { Johannesburg, South Africa }\end{array}$} \\
\hline \multicolumn{2}{|c|}{$\begin{array}{l}\text { Corresponding author: } \\
\text { Nadia Beringer, } \\
\text { nadia.beringer@gmail.com }\end{array}$} \\
\hline \multicolumn{2}{|c|}{$\begin{array}{l}\text { Dates: } \\
\text { Received: } 28 \text { July } 2021 \\
\text { Accepted: } 30 \text { Aug. } 2021 \\
\text { Published: } 29 \text { Oct. } 2021\end{array}$} \\
\hline \multicolumn{2}{|c|}{$\begin{array}{l}\text { How to cite this article: } \\
\text { Beringer N, Bennett KG, Poole } \\
\text { JE, Geel JA. Determinants of } \\
\text { survival in children with } \\
\text { cancer in Johannesburg, } \\
\text { South Africa. S. Afr. j. oncol. } \\
\text { 2021;5(0), a189. https://doi. } \\
\text { org/10.4102/sajo.v5i0.189 }\end{array}$} \\
\hline \multicolumn{2}{|c|}{$\begin{array}{l}\text { Copyright: } \\
\text { ( } 2021 \text {. The Authors } \\
\text { Licensee: AOSIS. This } \\
\text { is licensed under the } \\
\text { Creative Commons } \\
\text { Attribution License. }\end{array}$} \\
\hline \multicolumn{2}{|l|}{ Read online: } \\
\hline 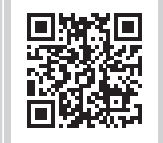 & $\begin{array}{l}\text { Scan this QR } \\
\text { code with your } \\
\text { smart phone or } \\
\text { mobile device } \\
\text { to read online. }\end{array}$ \\
\hline
\end{tabular}

Authors:

G. Bennett ${ }^{3}$

Janet E. Poole $\mathrm{e}^{1,2,3}$ (D)

Affiliations:

${ }^{1}$ Department of Paediatrics and Child Health, Faculty of Health Sciences, School of Clinical Medicine, University of the Witwatersrand

${ }^{2}$ Department of Paediatrics, Division of Paediatric Haematology and Oncology, Johannesburg Hospital,

${ }^{3}$ Department of Paediatric Oncology, Wits University Johannesburg, South Africa

Corresponding author:

Nadia Beringer,

Dates:

Received: 28 July 2021

Accepted: 30 Aug. 2021

How to cite this article: Beringer N, Bennett KG, Pool JE, Geel JA. Determinants of survival in children with South Africa. S. Afr. j. oncol. 2021;5(0), a189. https://doi.

Copyright:

(C) 2021. The Authors. Licensee: AOSIS. This work is licensed under the Creative Commons Attribution License.
Background: Childhood cancer, although rare, remains an important cause of death worldwide. The outcomes of children with all cancer types in South Africa are not well-documented.

Aim: The aim of the article was to determine local childhood cancer survival rates and establish determinants of survival.

Setting: The study was conducted at a state and a private hospital in South Africa.

Methods: This retrospective cohort study consecutively included all children with a proven malignancy from 01 January 2012 to 31 December 2016. Univariable and multivariable analyses were used to establish which factors significantly impacted overall survival (OS).

Results: Of a total of 677 study participants, 71\% were black South Africans. The estimated 5-year overall survival (OS) was 57\% (95\% confidence interval [CI]: 53-61\%) and significant determinants of OS on the multivariable analysis included: ethnicity, cancer-type and nutritional status. White and Indian patients had higher OS compared to black patients (hazard ration [HR] (95\% CI) $0.46(0.30-0.69) p=0.0002$ and $\operatorname{HR}(95 \%) 0.38(0.19-0.78) p=0.0087$, respectively). Underweight patients had inferior survival (HR (95\% CI) 1.78 (1.28-2.47)) $p=0.0006$. Patients with neuroblastoma had an increased risk of dying compared to those with leukaemia (HR [95\% CI] 1.78 [1.08-2.94]) $p=0.025$. Progression of disease was the most common cause of death, followed by disease relapse.

Conclusion: The childhood cancer survival rate obtained in this study can be used as a baseline to facilitate improvement. Non-modifiable prognostic factors included ethnicity and cancer-type whilst modifiable risk factors included undernutrition. Undernutrition should be addressed on a national and local level to improve survival.

Keywords: childhood cancer; survival; risk factors; undernutrition ; ethnicity; stage; South Africa.

\section{Introduction}

Despite childhood cancer being rare, representing approximately $1.2 \%$ of all malignant disease worldwide, the recorded incidence is increasing. ${ }^{1,2}$ At the same time, there has been an improvement in overall survival (OS) with the 5-year survival rate increasing from less than $30 \%$ in the early 1960 s to nearly $80 \%$ in the late 1990 s in many high income countries (HICs). ${ }^{3,4}$ Reliable data on the incidence and survival rates of childhood cancer are, however, only available for a small proportion of the world population and originate mostly from HICs. ${ }^{1,2}$ In these countries, in children aged 1-14 years, childhood cancer is ranked as one of the top five causes of death, and in the United States (US), it is surpassed only by trauma and congenital anomalies. ${ }^{5,6}$ In stark contrast, the World Health Organization (WHO) does not include cancer in the top five causes of death in children aged 1-14 years of age. ${ }^{7}$ These data are collected mostly from low- and middle-income countries (LMICs) such as sub-Saharan Africa and South Asia, where deaths are largely attributable to infectious diseases and neonatal complications. ${ }^{7,8}$ Many of these countries do not have adequate cancer registries and published reports thus have conflicting inferences. Despite the reported incidence being much lower in LMICs, it is postulated that up to $80 \%$ of children diagnosed with cancer live in these countries with a high childhood cancer mortality rate. ${ }^{8}$ However, sparse and inconsistent reporting means that these figures cannot be quantified. ${ }^{7,89}$ The equivalent published cancer mortality rate is $20 \%$ or lower in many HICs. ${ }^{3,4,9}$ In these HICs, the meticulous documentation of survival rates has facilitated the monitoring of treatment advances and has allowed a means to gauge improvements at both national and international levels. ${ }^{3,4}$ Although childhood cancer survival rates are frequently used as a monitoring tool in HICs, they are not routinely calculated in LMICs and therefore cannot be used for this purpose. ${ }^{8,10}$ 
South Africa (SA) is an upper-middle-income country (UMIC) with a population of approximately 59.62 million people, $29 \%$ of whom are under 15 years. ${ }^{11}$ It has a fragmented two-tiered healthcare system based on both privately funded and state-run services. This system may lead to inconsistent access to specialised medical services. The annual incidence of malignancies in South African children (aged 0-14 years) was reported to vary between 33.4 per million and 47.2 per million from 2003 to $2007 .{ }^{12}$ These figures are much lower than those documented in the United Kingdom (UK), Europe and the US over the same time period..$^{3,4,13}$ A likely explanation for this apparent discrepancy is under-reporting. Data on OS rates of childhood cancer from two South African centres were published in 2014. ${ }^{14}$ Despite this particular study being hospital-based, its survival rate of $52 \%$ was far lower than the rates obtained from population-based studies in similar upper-middle income settings. ${ }^{13,15}$ However, the true mortality of childhood cancer in South Africa remains unknown and was not included as a leading cause of death in children according to Statistics-SA 2016 (last year of study). ${ }^{16}$

It is essential to determine local and national childhood cancer survival rates in South Africa. These rates, together with any modifiable prognostic factors identified, can serve as a means to monitor and ultimately improve survival rates. This could serve as a mechanism to measure childhood cancer outcomes.

The aim of this study was therefore to determine childhood cancer survival rates in two hospitals (state and private) in Johannesburg, South Africa and to establish determinants of survival.

\section{Methods}

This retrospective cohort study spanned 5 years from 01 January 2012 to 31 December 2016. Patients from two paediatric oncology units (POUs), a privately funded academic institution, and a state facility, in Johannesburg, South Africa were included.

All children (aged 0-14 years) with a proven malignancy were consecutively enrolled during the study period. Oncology patients, seen and treated by other specialties, if never referred to their respective POU were not included in the analysis. Tumours were confirmed either histologically or radiologically (e.g. midline brain tumours and classical hepatoblastomas). These children were then grouped according to their malignancy into one of 12 diagnostic categories following the International Classification of Childhood Cancers 3rd Edition (ICCC-3).6,17 Data were abstracted from patients' files and included demographics, age at diagnosis, oncological diagnosis and stage. Age at diagnosis was categorised into approximate quintiles. The nutritional status at presentation, HIV status, date last seen and patient outcome at time of study were established. The last follow-up date was 30 June 2019. Lost to follow-up
(LTFU) could not be accurately assessed in this retrospective review, and therefore was not included in the analysis.

Basic anthropometry using weight and height was recorded at diagnosis and plotted using appropriate WHO growth standards charts (weight-for-age, length/height-for-age, weight-for length/height for age less than 5 years or body mass index (BMI) charts for patients that were older). Patients were then classified as either having a healthy (normal) or an unhealthy weight at diagnosis. ${ }^{18}$ A healthy weight was defined as a Z-score between -2 and +1 . An unhealthy weight was further subdivided into patients who were underweight at diagnosis (Z-score less than -2$)$; those at risk of being overweight (Z-score between +1 and +2 ); overweight (Z-score greater than +2 ) or obese (Z-score greater than +3 ). Ethnicity was self-reported according to SA racial groups. Stage at presentation was defined as 'early' versus 'late'. Early stage included those patients with either stage I or stage II disease at diagnosis, and late stage disease was made up of stage III, IV and V (the latter confined to bilateral nephroblastoma) tumours. International Classification of Childhood Cancers 3rd Edition Group I and III diagnostic categories cannot be staged and were included as their respective diagnostic categories (see tables), allowing all patients to be incorporated in the stage and survival analysis.

Causes of death included treatment-related mortality (TRM), disease-progression (DP), disease relapse or other. Treatment-related mortality encompassed adverse effects of chemotherapy (including neutropaenic and non-neutropaenic sepsis), radiation-toxicity and surgical complications. Disease-progression included those patients who did not attain remission; and disease relapse was diagnosed in patients with recurrence of disease after remission.

\section{Data analysis}

The association between study variables and hospital was determined by the chi-squared test (Fisher's exact test was used for $2 \times 2$ tables or where the assumptions of the chi-squared test were not met). Follow-up time was compared by the Wilcoxon Rank Sum test because the data did not meet the assumptions for the independent samples t-test. The effect of each study variable on OS was assessed by Cox Proportional Hazards regression. The proportional hazards assumption was checked by inspecting the survival and log-log-plots, as well as by adding a timecovariate term to the model and assessing its significance. Study variables significant at $p<0.2$ were combined into a multivariable model, after examining each pair of variables for possible confounding using the chi-squared test (or Fisher's exact test for $2 \times 2$ tables). A value of Cramer's $V$ (or the phi coefficient for Fisher's exact test) $>0.50$ was regarded as too strong an association to include both variables in the multivariable model. All two-factor interaction terms were tested in the model. Non-significant variables were sequentially removed from the multivariable 
model. Data analysis was carried out using SAS version 9.4 for Windows. A 5\% significance level was used.

\section{Ethical considerations}

Permission to conduct this retrospective analysis was obtained from the Human Research Ethics Committee of the University of the Witwatersrand (HREC M171005).

\section{Results}

Between 01 January 2012 and 31 December 2016, 677 patients were diagnosed with paediatric malignancies, 411 (60.7\%) of whom were treated at the state hospital and 266 (39.3\%) at the private facility. The demographic and clinical characteristics of the patients are presented in Table 1, which also shows a comparison of the patient profile between the two hospitals.

The majority of the patients $(71.3 \%)$ were self-identified as Black South African. There was a higher proportion of White, and a lower proportion of Black patients at the private facility compared to the state facility $(p<0.0001)$. There were an almost equal proportion of Indian and mixed race patients (38 versus 37) at both POUs combined. More foreign patients (from neighbouring African countries) were seen at the private hospital $(p=0.0006)$.

The median age at diagnosis was 5.38 years (interquartile range [IQR]: 2.63-10.07 years) with a male to female ratio of 1:0.85. Six hundred and sixty patients had documented HIV results, the majority of whom were HIV negative (93.6\%). Of the patients who tested HIV positive, $60 \%$ presented with an acquired immunodeficiency syndrome (AIDS) defining malignancy. ${ }^{19}$

Anthropometric data at presentation were available for 602 patients and $71.4 \%$ of these had a healthy weight at diagnosis. A larger proportion of patients were classified as underweight for age at the state facility and overweight or obese at the private hospital $(p=0.0001)$. Patients who were overweight or obese at presentation seemingly fared better, however this was not statistically significant. The OS of those underweight at diagnosis was significant on both the uni- and multivariable analysis.

Overall, the most common ICCC-3 diagnostic category was Group I tumours (leukaemias, myeloproliferative disease and myelodysplastic diseases), and comprised $25.0 \%$ of the study population. Group III tumours (central nervous syndrome [CNS] and miscellaneous intracranial and intraspinal neoplasms) were the second most common (19.1\%), followed by lymphomas and reticuloendothelial neoplasms (Group II tumours) at 13.7\%.

As shown in Table 1, the overall comparison of stage (early and late) between the two hospitals was significant $(p=0.0004)$. More patients presented with early stage disease at the state compared to the private facility $(29.3 \%$ vs. $18.5 \%)$.
There was, however, only a small difference in the percentage of late stage disease between the two POUs (31.8\% vs. $27.9 \%$ ). Apart from the patients who presented with ICCC-3 Group I and III tumours, 12 patients with Kaposi Sarcoma could not be staged.

The estimated 5-year OS of the entire cohort was 57\% (95\% confidence interval [CI] 53\% - 61\%). The follow-up time at both POUs was 2.7 years, with an IQR of $0.4-4.6$ years. At final follow-up, $40.3 \%$ (or 273 out of 677 patients) were reported to have died. Disease-progression was the number one cause of death $(115 / 273,42.1 \%)$ at both POUs combined. This was followed by disease relapse (95 patients, 34.8\%) with TRM being the third most common cause (53 patients $19.4 \%$ ). Ten patients $(3.7 \%)$ died from unknown or other causes. On closer examination, DP was the predominant cause of death in ICCC-3 Group III, IV and VIII. Relapse as a cause of death was the most common in ICCC-3 Group I, II and IX. The remaining ICCC-3 groups were small and therefore causes of death could not be accurately assessed (See Figure 1). A higher proportion of patients succumbed to disease relapse, whilst a smaller number died from both DP and TRM at the private compared to the state hospital ( $p=0.0056)$. Treatment-related mortality included those patients who succumbed to treatment-related toxicity, as well as those who were denied access to an intensive care unit (ICU) if required because of the lack of ICU capacity.

Table 2 depicts the univariable analysis showing no significant relationships amongst OS, age at diagnosis, sex, tumour type (haematological vs. solid) and HIV status. Ethnicity was found to be significant with White and Asian/Indian patients having an improved OS compared to Black patients $(p<0.0001$ and $p=0.020$, respectively). Patients diagnosed with neuroblastoma and other peripheral nerve cell tumours (ICCC-3 group IV) had significantly worse outcomes overall (hazard ratio [HR] [95\% CI] 1.73 [1.07-2.81]) $(p=0.026)$. On univariable analysis, those who were underweight at diagnosis $(p<0.0001)$ had an increased chance of dying. Patients who presented to the private facility had a better OS than those who presented to the state hospital (HR [95\% CI] 0.77 [0.60-0.99]) $p=0.043$.

The multivariable analysis included all study participants with complete data (602 out of 677 patients). It found that the hospital (state vs. private), patient nationality and stage at presentation were not significant determinants of survival (Table 3). Prognostic factors included: ethnicity, ICCC-3 classification and nutritional status. Both White and Indian patients had a lower risk of dying compared to Black patients (HR [95\% CI] $0.46 \quad[0.30-0.69])$ and 0.38 [0.19-0.78]), respectively (Figure 2a). The OS of patients who presented with ICCC-3 category II, V, VI, X was significantly better than ICCC-3 category I. Again, ICCC-3 category IV tumours had a lower OS (HR [95\% CI] 1.78 [1.28-2.47]) (Figure 2b). Those who were underweight at diagnosis also did worse (HR [95\% CI] 1.78 [1.28-2.47] (Figure 2c). 
TABLE 1: Descriptive analysis: State and private hospital.

\begin{tabular}{|c|c|c|c|c|c|c|c|c|c|c|c|c|c|c|}
\hline \multirow[t]{2}{*}{ Characteristic } & \multirow[t]{2}{*}{ Category } & \multicolumn{4}{|c|}{ Overall $(n=677)$} & \multicolumn{4}{|c|}{ State hospital $(n=411)$} & \multicolumn{4}{|c|}{ Private hospital $(n=266)$} & \multirow[t]{2}{*}{$p$} \\
\hline & & $n$ & $\%$ & Median & IQR & $n$ & $\%$ & Median & IQR & $n$ & $\%$ & Median & IQR & \\
\hline \multirow[t]{4}{*}{ Age at diagnosis (years) } & $<1$ years & 49 & 7.2 & - & - & 24 & 5.8 & - & - & 25 & 9.4 & - & - & 0.094 \\
\hline & $1-4$ years & 270 & 39.9 & - & - & 157 & 38.2 & - & - & 113 & 42.5 & - & - & \\
\hline & $5-9$ years & 186 & 27.5 & - & - & 115 & 28.0 & - & - & 71 & 26.7 & - & - & \\
\hline & $10-14$ years & 172 & 25.4 & - & - & 115 & 28.0 & - & - & 56 & 21.4 & - & - & \\
\hline \multirow[t]{2}{*}{ Sex } & Male & 366 & 54.1 & - & - & 218 & 53.0 & - & - & 148 & 55.6 & - & - & 0.53 \\
\hline & Female & 311 & 45.9 & - & - & 193 & 47.0 & - & - & 118 & 44.4 & - & - & \\
\hline \multirow[t]{4}{*}{ Ethnicity } & Black people & 483 & 71.3 & - & - & 339 & 82.5 & - & - & 144 & 54.1 & - & - & $<0.0001$ \\
\hline & White people & 119 & 17.6 & - & - & 28 & 6.8 & - & - & 91 & 34.2 & - & - & \\
\hline & Asian/Indian people & 38 & 5.6 & - & - & 18 & 4.4 & - & - & 20 & 7.5 & - & - & \\
\hline & Mixed race people & 37 & 5.5 & - & - & 26 & 6.3 & - & - & 11 & 4.1 & - & - & \\
\hline \multirow[t]{2}{*}{ Nationality } & South African & 540 & 79.8 & - & - & 346 & 84.2 & - & - & 194 & 72.9 & - & - & 0.0006 \\
\hline & Foreign & 137 & 20.2 & - & - & 65 & 15.8 & - & - & 72 & 27.1 & - & - & \\
\hline \multirow[t]{2}{*}{ Hospital } & State & 411 & 60.7 & - & - & - & - & - & - & - & - & - & - & \\
\hline & Private & 266 & 39.3 & - & - & - & - & - & - & - & - & - & - & \\
\hline \multirow[t]{12}{*}{ ICCC-3 classification } & I-Leukaemias, MPS, MDS & 169 & 25.0 & - & - & 71 & 17.3 & - & - & 98 & 36.8 & - & - & $<0.0001$ \\
\hline & III-CNS tumours & 129 & 19.1 & - & - & 85 & 20.7 & - & - & 44 & 16.5 & - & - & \\
\hline & $\begin{array}{l}\text { II-Lymphomas } \\
\text { and reticuloendothelial neoplasms }\end{array}$ & 93 & 13.7 & - & - & 67 & 16.3 & - & - & 26 & 9.8 & - & - & \\
\hline & $\begin{array}{l}\text { IX-Soft tissue and other extraosseous } \\
\text { sarcomas }\end{array}$ & 68 & 10.0 & - & - & 50 & 12.2 & - & - & 18 & 6.8 & - & - & \\
\hline & VI-Renal Tumours & 63 & 9.3 & - & - & 41 & 10.0 & - & - & 22 & 8.3 & - & - & \\
\hline & V-Retinoblastoma & 35 & 5.2 & - & - & 25 & 6.1 & - & - & 10 & 3.8 & - & - & \\
\hline & $\begin{array}{l}\text { IV-Neuroblastoma and other peripheral } \\
\text { nervous cell tumours }\end{array}$ & 34 & 5.0 & - & - & 16 & 3.9 & - & - & 18 & 6.8 & - & - & \\
\hline & VIII-Malignant bone tumours & 29 & 4.3 & - & - & 17 & 4.1 & - & - & 12 & 4.5 & - & - & \\
\hline & $\begin{array}{l}\text { X-Germ Cell Tumours, trophoblastic tumours } \\
\text { and neoplasms of gonads }\end{array}$ & 29 & 4.3 & - & - & 21 & 5.1 & - & - & 8 & 3.0 & - & - & \\
\hline & $\begin{array}{l}\text { XI-Other malignant epithelial neoplasms and } \\
\text { malignant melanomas }\end{array}$ & 15 & 2.2 & - & - & - & - & - & - & - & - & - & - & \\
\hline & VII-Hepatic tumours & 9 & 1.3 & - & - & 18 & 4.4 & - & - & 10 & 3.8 & - & - & \\
\hline & $\begin{array}{l}\text { XII-Other and unspecified malignant } \\
\text { neoplasms }\end{array}$ & 4 & 0.6 & - & - & - & - & - & - & - & - & - & - & \\
\hline \multirow[t]{2}{*}{ Tumour type } & Haematological (ICCC-3 Group I+II) & 260 & 38.4 & - & - & 136 & 33.1 & - & - & 124 & 46.6 & - & - & 0.0005 \\
\hline & Solid & 417 & 61.6 & - & - & 275 & 66.9 & - & - & 142 & 53.4 & - & - & \\
\hline 1-Leukaemias, MPS, MDS & ALL & 122 & 87.5 & - & - & - & - & - & - & - & - & - & - & \\
\hline & AML & 48 & 37.5 & - & - & - & - & - & - & - & - & - & - & \\
\hline & $\mathrm{CML}$ & 1 & 0.8 & - & - & - & - & - & - & - & - & - & - & \\
\hline & Other (JMML, ALAL etc.) & 7 & 5.5 & - & - & - & - & - & - & - & - & - & - & \\
\hline & Unknown & 1 & & - & - & - & - & - & - & - & - & - & - & \\
\hline 2-Lymphomas and & $\mathrm{HL}$ & 33 & 35.9 & - & - & - & - & - & - & - & - & - & - & \\
\hline subtype $(n=93)$ & $\mathrm{NHL}$ & 59 & 64.1 & - & - & - & - & - & - & - & - & - & - & \\
\hline & Unknown & 1 & & - & - & - & - & - & - & - & - & - & - & \\
\hline Early/late stage & Early & 166 & 25.0 & - & - & 117 & 29.3 & - & - & 49 & 18.5 & - & - & 0.0004 \\
\hline & Late & 201 & 30.2 & - & - & 127 & 31.8 & - & - & 74 & 27.9 & - & - & \\
\hline & N/A (ICCC-3: I+III) & 298 & 44.8 & - & - & 156 & 39.0 & - & - & 142 & 53.6 & - & - & \\
\hline & Not staged & 12 & - & - & - & - & - & - & - & - & - & - & - & \\
\hline Stage & 1 & 92 & 13.8 & - & - & 65 & 16.3 & - & - & 27 & 10.2 & - & - & 0.0017 \\
\hline & 2 & 73 & 11.0 & - & - & 51 & 12.8 & - & - & 22 & 8.3 & - & - & \\
\hline & 3 & 102 & 15.3 & - & - & 60 & 15.0 & - & - & 42 & 15.8 & - & - & \\
\hline & 4 & 97 & 14.6 & - & - & 68 & 17.0 & - & - & 32 & 12.1 & - & - & \\
\hline & 5 & 3 & 0.5 & - & - & 68 & 17.0 & - & - & 32 & 12.1 & - & - & \\
\hline & N/A (ICCC-3: I+III) & 298 & 44.8 & - & - & 156 & 39.0 & - & - & 142 & 53.6 & - & - & \\
\hline & Not staged & 12 & - & - & - & - & - & - & - & - & - & - & - & \\
\hline HIV status & Negative & 618 & 93.6 & - & - & 368 & 90.4 & - & - & 250 & 98.8 & - & - & $<0.0001$ \\
\hline & Positive & 42 & 6.4 & - & - & 39 & 9.6 & - & - & 3 & 1.2 & - & - & \\
\hline & Unknown & 17 & - & - & - & - & - & - & - & - & - & - & - & \\
\hline Nutritional classification & UW & 88 & 14.6 & - & - & 65 & 18.5 & - & - & 23 & 9.2 & - & - & 0.0001 \\
\hline & HW & 430 & 71.4 & - & - & 250 & 71.0 & - & - & 180 & 72.0 & - & - & \\
\hline & Risk of OW & 55 & 9.1 & - & - & 29 & 8.2 & - & - & 26 & 10.4 & - & - & \\
\hline & OW & 26 & 4.3 & - & - & 8 & 2.3 & - & - & 21 & 8.4 & - & - & \\
\hline & $\mathrm{OB}$ & 3 & 0.5 & - & - & 8 & 2.3 & - & - & 21 & 8.4 & - & - & \\
\hline & ND & 75 & - & - & - & - & - & - & - & - & - & - & - & \\
\hline
\end{tabular}


TABLE 1 (Continues...): Descriptive analysis: State and private hospital.

\begin{tabular}{|c|c|c|c|c|c|c|c|c|c|c|c|c|c|c|}
\hline \multirow[t]{2}{*}{ Characteristic } & \multirow[t]{2}{*}{ Category } & \multicolumn{4}{|c|}{ Overall $(n=677)$} & \multicolumn{4}{|c|}{ State hospital $(n=411)$} & \multicolumn{4}{|c|}{ Private hospital $(n=266)$} & \multirow[t]{2}{*}{$p$} \\
\hline & & $n$ & $\%$ & Median & IQR & $n$ & $\%$ & Median & IQR & $n$ & $\%$ & Median & IQR & \\
\hline \multirow[t]{5}{*}{ Cause of death $(n=273)$} & $\mathrm{DP}$ & 115 & 42.3 & - & - & 85 & 47.8 & - & - & 30 & 31.6 & - & - & \multirow[t]{5}{*}{0.0056} \\
\hline & Relapse & 95 & 34.9 & - & - & 49 & 27.5 & - & - & 46 & 48.4 & - & - & \\
\hline & TRM & 53 & 19.5 & - & - & 37 & 20.8 & - & - & 16 & 16.8 & - & - & \\
\hline & Other (KS) & 9 & 3.3 & - & - & 7 & 3.9 & - & - & 2 & 2.1 & - & - & \\
\hline & Unknown & 1 & - & - & - & - & - & - & - & - & - & - & - & \\
\hline
\end{tabular}

SA, South Africa; ICCC-3, International Classification of Childhood Cancer 3rd edition; ALL, acute lymphoblastic leukaemia; AML, acute myeloid leukaemia; CML, chronic myeloid leukaemia; ALAL, acute leukaemia of ambiguous lineage; JMML, juvenile myelomonocytic leukaemia; MPS, myeloproliferative syndrome; MDS, myelodysplastic syndrome; CNS, central nervous syndrome; UW, underweight; HW, healthy weight; OW, overweight; OB, obese; ND, not done; LTFU, lost to follow up; DP, disease progression; TRM, treatment related mortality; KS, Kaposi Sarcoma; IQR,

interquartile range; HL, Hodgkin lymphoma; NHL, non-Hodgkin lymphoma; HIV, human immunodeficiency virus.

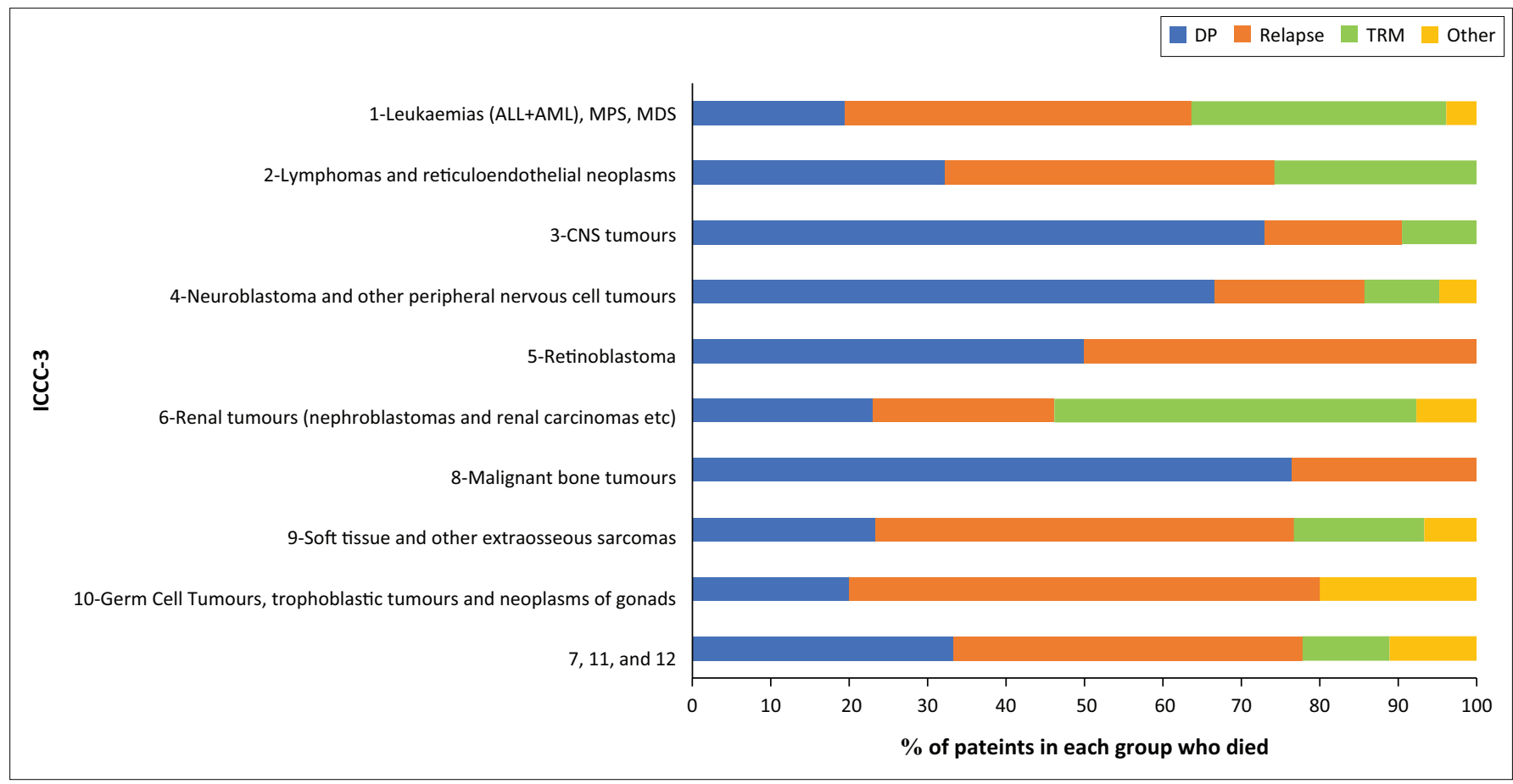

MPS, myeloproliferative syndrome; MDS, myelodysplastic syndrome; CNS, central nervous syndrome; TRM, treatment-related mortality; DP, disease-progression ; ICCC-3, International Classification of Childhood Cancer 3rd edition.

FIGURE 1: Causes of death per International Classification of Childhood Cancers 3rd edition category.

\section{Discussion}

Knowledge of local and national childhood cancer survival rates is important, and can be used as a baseline to monitor diagnosis, management and survival trends. The current study involved two POUs (state and private) in Johannesburg, South Africa. It determined local childhood cancer survival rates and identified significant determinants of survival. These determinants comprised: patient ethnicity; type of tumour and nutritional status at presentation. The study results are likely to represent national data as it included both a state and private facility, and highlighted the discrepancies and similarities between the two. However, differing geographical and socio-economic conditions may have influenced patient outcomes.

Patient ethnicity, although self-identified, largely reflected the national population demographics during this time (black South African patients making up the large majority). In this study, black patients fared the worst. Although the country celebrated its 18th year as a democratic republic in 2012 (first year of the study), marked social discrepancies are still very widespread and the gap between state and private health access has not reduced noticeably in size. This discrepancy definitely contributed to the type of healthcare (state vs. private) that an individual patient accessed. Today, more acceptable parameters (instead of racial grouping) would include level of maternal education and household income, transport, etc. These surrogate parameters will highlight the differing socio-economic situations in our country.

More than half of the study participants presented with a healthy weight, and as was expected did better. ${ }^{20}$ Patients who were underweight at diagnosis also fared worse than those overweight or obese.

In the current study, the three most common childhood malignancies were acute leukaemias (ICCC-3 Group I), CNS tumours (Group III) and lymphomas (Group II). This 
TABLE 2: Univariable analysis: Childhood cancer determinants of overall survival $(n=677)$.

\begin{tabular}{|c|c|c|c|}
\hline Characteristic & Category & HR for death & $95 \% \mathrm{Cl}$ for $\mathrm{HR}$ \\
\hline \multirow{4}{*}{$\begin{array}{l}\text { Age at diagnosis } \\
\text { (years) }\end{array}$} & $<1$ year & 1.00 & Reference \\
\hline & $1-4$ years & 1.04 & $0.62-1.74$ \\
\hline & $5-9$ years & 1.29 & $0.76-2.18$ \\
\hline & $10-14$ years & 1.25 & $0.74-2.11$ \\
\hline \multirow[t]{2}{*}{ Sex } & Male & 1.00 & Reference \\
\hline & Female & 1.00 & $0.79-1.26$ \\
\hline \multirow[t]{4}{*}{ Ethnicity } & Black people & 1.00 & Reference \\
\hline & White people & 0.47 & $0.32-0.68$ \\
\hline & Asian/Indian people & 0.47 & $0.25-0.89$ \\
\hline & Mixed race people & 0.72 & $0.42-1.23$ \\
\hline \multirow[t]{2}{*}{ Nationality } & South African & 1.00 & Reference \\
\hline & Foreign & 1.51 & $1.14-1.99$ \\
\hline \multirow[t]{2}{*}{ Hospital } & State & 1.00 & Reference \\
\hline & Private & 0.77 & $0.60-0.99$ \\
\hline \multirow[t]{10}{*}{ ICCC-3 classification } & I-Leukaemias MPS, MDS & 1.00 & Reference \\
\hline & III-CNS tumours & 1.23 & $0.88-1.72$ \\
\hline & $\begin{array}{l}\text { II- Lymphomas and } \\
\text { reticuloendothelial neoplasms }\end{array}$ & 0.70 & $0.46-1.06$ \\
\hline & $\begin{array}{l}\text { IX-Soft tissue and other } \\
\text { extraosseous sarcomas }\end{array}$ & 0.93 & $0.61-1.42$ \\
\hline & $\begin{array}{l}\text { VI-Renal tumours } \\
\text { (Nephroblastoma, renal } \\
\text { carcinoma etc.) }\end{array}$ & 0.40 & $0.22-0.71$ \\
\hline & V-Retinoblastoma & 0.40 & $0.19-0.87$ \\
\hline & $\begin{array}{l}\text { IV-Neuroblastoma and other } \\
\text { peripheral nervous cell } \\
\text { tumours }\end{array}$ & 1.73 & $1.07-2.81$ \\
\hline & VIII-Malignant bone tumours & 1.46 & $0.86-2.47$ \\
\hline & $\begin{array}{l}\text { X-Germ Cell Tumours, } \\
\text { trophoblastic tumours and } \\
\text { neoplasms of gonads }\end{array}$ & 0.32 & $0.13-0.79$ \\
\hline & $\mathrm{VII}, \mathrm{XI}$, and XII & 0.68 & $0.34-1.36$ \\
\hline \multirow[t]{2}{*}{ Tumour type } & Haematological & 1.00 & Reference \\
\hline & Solid & 1.01 & $0.79-1.28$ \\
\hline \multirow[t]{4}{*}{ Early/late stage } & Early & 1.00 & Reference \\
\hline & Late & 5.22 & $3.27-8.34$ \\
\hline & N/A (ICCC-3: I + III) & 4.52 & $2.86-7.15$ \\
\hline & Not staged & - & - \\
\hline \multirow[t]{6}{*}{ Stage } & 1 & 1.00 & Reference \\
\hline & 2 & 2.25 & $0.90-5.63$ \\
\hline & 3 & 5.95 & $2.68-13.2$ \\
\hline & $4 / 5$ & 12.3 & $5.66-26.9$ \\
\hline & N/A (ICCC-3: I + III) & 7.43 & $3.48-15.9$ \\
\hline & Not staged & - & - \\
\hline \multirow[t]{3}{*}{ HIV status } & Negative & 1.00 & Reference \\
\hline & Positive & 1.07 & $0.65-1.75$ \\
\hline & Unknown & - & - \\
\hline \multirow{5}{*}{$\begin{array}{l}\text { Nutritional } \\
\text { classification }\end{array}$} & UW & 2.03 & $1.48-2.80$ \\
\hline & $\mathrm{HW}$ & 1.00 & Reference \\
\hline & Risk of OW & 0.97 & $0.60-1.57$ \\
\hline & OW/OB & 0.61 & $0.29-1.31$ \\
\hline & ND & - & - \\
\hline
\end{tabular}

SA, South Africa; ICCC-3, International Classification of Childhood Cancer-3rd edition; ALL, acute lymphoblastic leukaemia; AML, acute myeloid leukaemia; MPS, myeloproliferative syndrome; MDS, myelodsplastic syndrome; CNS, central nervous syndrome; UW, underwe;

is similar to results from both HICs and LMICs that rank these as the most common occurring tumours. ${ }^{2}$ The ICCC3 classification proved to be a significant determinant of patient survival. Because not all childhood cancer ICCC-3 tumours behave similarly, this was not an unexpected study finding. For example, neuroblastoma is known to behave unpredictably, with an unsatisfactory OS especially in late stage disease, as was proven in this study.
TABLE 3: Multivariable analysis: Childhood cancer determinants of overall survival $(n=602)$

\begin{tabular}{|c|c|c|c|c|}
\hline Characteristic & Category & $p$ & HR for death & $95 \% \mathrm{Cl}$ for $\mathrm{HR}$ \\
\hline \multirow[t]{4}{*}{ Ethnicity } & Black people & - & 1.00 & Reference \\
\hline & White people & 0.0002 & 0.46 & $0.30-0.69$ \\
\hline & Asian/Indian people & 0.0087 & 0.38 & $0.19-0.78$ \\
\hline & Mixed race people & 0.2000 & 0.68 & $0.38-1.23$ \\
\hline \multirow[t]{10}{*}{$\begin{array}{l}\text { ICCC-3 } \\
\text { classification }\end{array}$} & $\begin{array}{l}\text { I- Leukaemias, MPS, } \\
\text { MDS }\end{array}$ & - & 1.00 & Reference \\
\hline & III-CNS tumours & 0.6500 & 1.09 & $0.75-1.61$ \\
\hline & $\begin{array}{l}\text { II-Lymphomas and } \\
\text { reticuloendothelial } \\
\text { neoplasms }\end{array}$ & 0.0390 & 0.61 & $0.39-0.98$ \\
\hline & $\begin{array}{l}\text { IX-Soft tissue and other } \\
\text { extraosseous sarcomas }\end{array}$ & 0.7500 & 1.07 & $0.69-1.67$ \\
\hline & $\begin{array}{l}\text { VI-Renal tumours } \\
\text { (Nephroblastoma, renal } \\
\text { carcinoma etc.) }\end{array}$ & 0.0010 & 0.35 & $0.19-0.66$ \\
\hline & V-Retinoblastoma & 0.0380 & 0.44 & $0.20-0.95$ \\
\hline & $\begin{array}{l}\text { IV-Neuroblastoma and } \\
\text { other peripheral } \\
\text { nervous cell tumours }\end{array}$ & 0.0250 & 1.78 & $1.08-2.94$ \\
\hline & $\begin{array}{l}\text { VIII-Malignant bone } \\
\text { tumours }\end{array}$ & 0.7800 & 0.91 & $0.48-1.74$ \\
\hline & $\begin{array}{l}\text { X-Germ Cell Tumours, } \\
\text { trophoblastic tumours } \\
\text { and neoplasms of } \\
\text { gonads }\end{array}$ & 0.0100 & 0.27 & $0.10-0.73$ \\
\hline & $\mathrm{VII}, \mathrm{XI}$, and $\mathrm{XII}$ & 0.3600 & 0.71 & $0.34-1.48$ \\
\hline \multirow{4}{*}{$\begin{array}{l}\text { Nutritional } \\
\text { classification }\end{array}$} & UW & 0.0006 & 1.78 & $1.28-2.47$ \\
\hline & HW & - & 1.00 & Reference \\
\hline & Risk of OW & 0.9900 & 1.00 & $0.62-1.62$ \\
\hline & $\mathrm{OW} / \mathrm{OB}$ & 0.3700 & 0.71 & $0.33-1.51$ \\
\hline
\end{tabular}

ICCC-3, International Classification of Childhood Cancer-3rd edition; UW, underweight; HW, healthy weight: OW, overweight; OB, obese; ; MPS, myeloproliferative syndrome; MDS, myelodysplastic syndrome; CNS, central nervous syndrome; $\mathrm{Cl}$, confidence interval; $\mathrm{HR}$, hazard ratio.

More patients presented with early stage disease at the state facility compared to the private facility. A possible explanation is that there are many cancer awareness campaigns occurring predominately in state facilities. ${ }^{21}$ These campaigns include cancer early warning signs that target the patients and their families. Numerous studies have, however, demonstrated that medical factors play more of an important role in increased diagnostic lag time than parental/patient factors. ${ }^{22}$ Therefore, this unexpected study finding was likely because of chance.

Six per cent of the total study population tested HIV positive. This was higher than the national published incidence rate of $2.4 \%((95 \% \mathrm{CI}) 1.9 \%-2.9 \%)$ in children $(0-14$ years) in the first year of the study ${ }^{23}$ and is explained by the fact that people infected with HIV have a substantially higher risk of certain types of cancer compared with uninfected people of the same age. ${ }^{24}$

Despite the significant differences noted on the descriptive and univariable analysis between the two hospitals, this was not demonstrated in the multivariable model and was, therefore, the choice of the hospital (state vs. private) was not found to independently impact OS in the study population. In this study, both POUs share similarities as well as many discrepancies. The same paediatric oncology doctors rotate through each hospital, with the same 
diagnostic tools and identical treatment protocols. Children treated at both POUs are taught meticulous mouth care with prophylactic antifungal mouth ointment and receive ongoing prophylactic antibiotics, such as thrice weekly cotrimoxazole in an attempt to prevent Pneumocystis jerovicii infections. Those with suspected neutropaenic sepsis are isolated and receive swift antibiotic administration according to the local antibiogram at both facilities. The state hospital has a $24-\mathrm{h}$ casualty with doctors available at all times, whilst the private facility does not have a casualty but does have easier access to ICU facilities and more advanced supportive care. But, as there was no significant difference in survival between the state and private facility, it would appear that the management of childhood cancer at both hospitals is standardised.

The most common cause of death was DP with the majority of these patients presenting with solid tumours (nearly half of whom had brain tumours). There was an unsurprising finding as $78.7 \%$ of these patients had WHO Grade IV brain tumours. Treatment-related mortality, the third most common cause of death, is potentially avoidable. These patients need expeditious treatment of any suspected sepsis, following local antibiograms and not infrequently requiring supportive care (either high care or intensive care). However, in this study, we were largely unable to quantify the level of supportive care offered to these patients at the time of death because of the lack of documentation. High care facilities are not widely available in the state sector, and intensive care is extremely difficult to secure. Intensive care unit requests were often not filed or documented if telephonic. The most common reasons cited as to why intensive care was declined in these patients was ICU bed availability and also if the patient was considered a poor candidate, after discussion with the paediatric intensivist on call.

In the study, the estimated OS of childhood cancer was $57 \%$. As we strive to improve our national overall childhood cancer survival rates, it becomes important to compare these rates and to determine potentially modifiable factors. Although the current study was a hospital- and not a population-based study and involved only two POUs in SA, we compared international data with our study findings.

Like South Africa, Thailand is an UMIC with a reported childhood cancer OS of $47.2 \%$ from a population-based study for the period 2001-2011. ${ }^{25}$ Brazil, another UMIC recorded a relative 5 -year of $65 \%$ in children with cancer in the Midwest (population-based) between 2004 and 2012. ${ }^{26}$ In HIC Japan, the childhood cancer 5-year OS (population-based) from 1998 to 2000 was 79\% some
20 years prior to our study. ${ }^{27}$ Similarly, the UK reported 5 -year OS from 2011 to 2015 of $84 \%$ and in 2011, in the United States, $83.5 \%$ of those diagnosed with childhood cancer survived more than 5 years after their cancer diagnosis. $^{28,29}$ Results from EUROCARE-5, another population-based study from 29 countries in Europe showed a 79.11\% 5-year OS from 2005 to $2007 .^{4}$

However, when comparing survival rates with those from other countries, it is important to consider that there are appreciable differences amongst high-income, uppermiddle- and low-income countries. These differences include, amongst others, infrastructure and socioeconomical discrepancies. High income countries often have better referral pathways, availability of healthcare and infrastructure which may allow for an earlier stage at presentation. These countries are more likely to have a higher physician to patient/population ratio and are able to provide better supportive care, including blood products, ICU facilities, medicine and staff. The improved socio-economics theoretically allows for better nutrition of the patient at the time of diagnosis and an earlier stage at presentation.

\section{Limitations}

This study included results from only two POUs and the retrospective design accounted for missing data. The classification of childhood cancers according to the ICCC3 , stage at presentation and cause of death was often assigned in retrospect. Use of the ICCC-3 allowed for an overview rather than a detailed analysis of each disease subgroup. Possible more meaningful determinants of OS such as maternal education and individual socio-economic conditions were not included. Patients with large tumours may have been incorrectly classified as having a normal weight at diagnosis. Serum nutritional biomarkers and metric measurements were also not routinely recorded and therefore could not be used. A mid-upper arm circumference (MUAC) (a nutritional metric measurement) was not routinely done in this study, nor incorporated into the patient weight classification. Although chemoand radiotherapy protocols, indications for surgery and initial management of febrile neutropaenia were the same in the two POUs, we were unable to ensure total standardisation of care.

\section{Recommendations}

We recommend a nationwide gathering of data on childhood cancer to determine OS rates. The South African Children's Tumour Registry (SACCSG) established over 30 years ago collects data on malignant disease in the paediatric population through hospital-based registries. These registries record data on patients presenting to national paediatric oncology services, but often do not include accurate mortality data. ${ }^{30}$ Healthcare workers, therefore, need to be educated with 


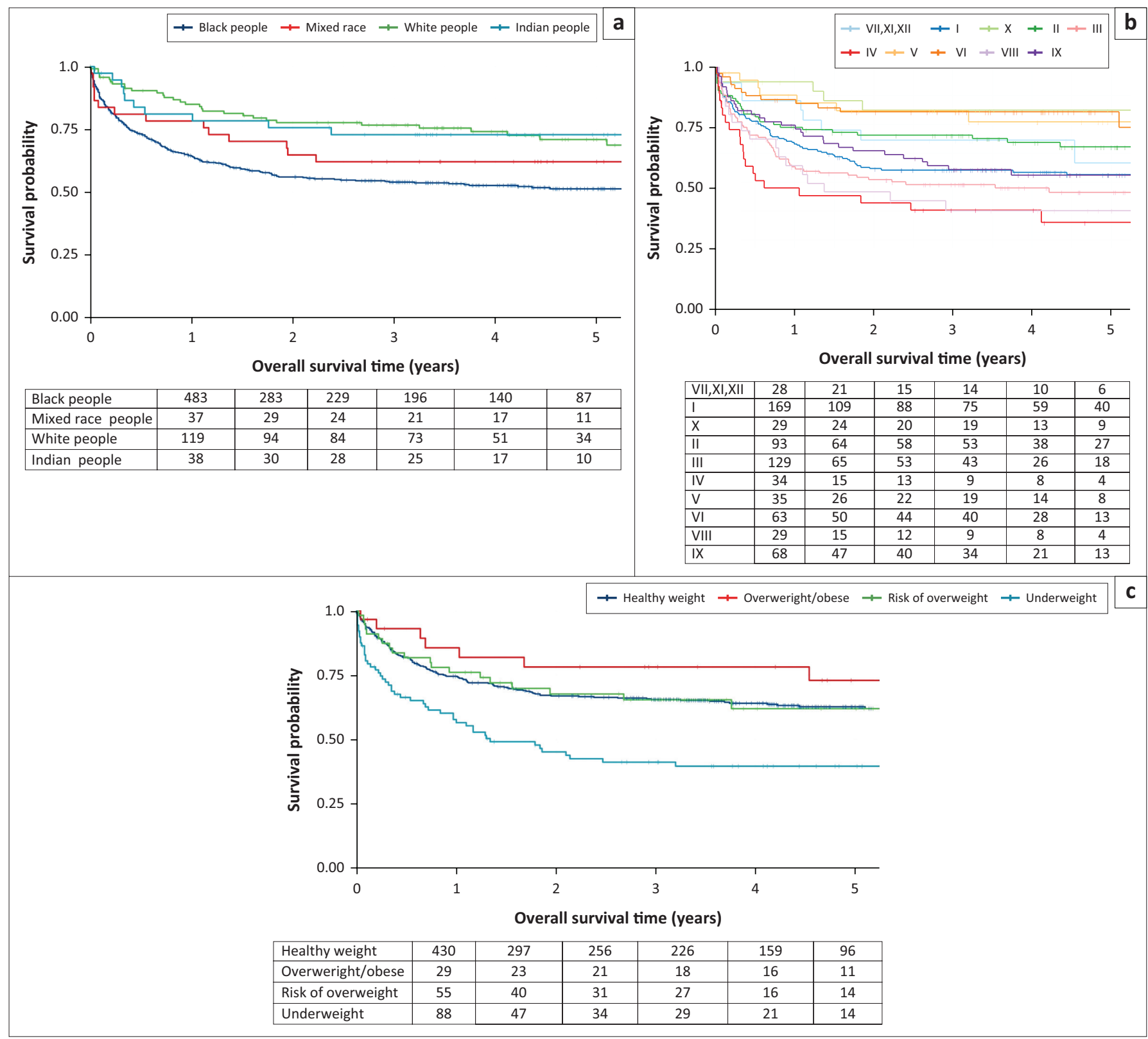

FIGURE 2: Kaplan-Meier plots showing the effect of (a) ethnicity, (b) International Classification of Childhood Cancers 3rd edition classification and (c) nutritional status, on overall survival in childhood cancer.

regard to the importance of accurately collecting and providing these data.

\section{Conclusion}

The current study examined determinants of survival of childhood cancer in a small subpopulation of South African children. Prognostic factors and reversible causes of death were determined to facilitate improvement in survival. As we strive towards increasing our national survival rate to approach that of other upper-middle and HICs, the OS rate attained in this study must be improved on. A significant modifiable factor identified includes addressing the nutritional status of patients at presentation. Treatment-related mortality is a cause of death that is potentially preventable and is, therefore, an area that should be targeted too. This will include improving the supportive care offered to these patients, including ICU facilities.

\section{Acknowledgements Competing interests}

The authors declare that they have no financial or personal relationships that may have inappropriately influenced them in writing this article.

\section{Authors' contributions}

Each author contributed significantly to the final manuscript. All authors made substantial contributions to the conception and design, the acquisition of data and the analysis and interpretation thereof. The principal author (N.B.) drafted the manuscript but all co-authors critically revised it and approved the article. 


\section{Funding information}

The Wits Donald Gordon Medical Centre provided financial support towards the statistical analysis of this article.

\section{Data availability}

Data sharing is not applicable to this article as no new data were created or analysed in this study.

\section{Disclaimer}

The views and opinions expressed in this article are those of the authors and do not necessarily reflect the official policy or position of any affiliated agency of the authors.

\section{References}

1. Steliarova-Foucher E, Colombet M, Ries LAG, et al. International incidence of childhood cancer, 2001-10: A population-based registry study. Lancet Oncol. 2017;18(6):719-731. https://doi.org/10.1016/S1470-2045(17)30186-9

2. Rodriguez-Galindo $C$, Friedrich $P$, Alcasabas $P$, et al. Toward the cure of all children with cancer through collaborative efforts: Pediatric Oncology as a global challenge. J Clin Oncol. 2015;33(27):3065-3073. https://doi.org/10.1200/JCO.2014.60.6376

3. Cancer Research UK [homepage on the Internet]. [cited 2019 Nov 13]. Available from: https://www.cancerresearchuk.org/health-professional/cancer-statistics/ childrens-cancers/survival

4. Linet MS, Ries LAG, Smith MA, Tarone RE, Devesa SSQ. Cancer surveillance series. Recent trends in childhood cancer incidence and mortality in the United States. JNCI. 1999;91(12):1051-1058. https://doi.org/10.1093/jnci/91.12.1051

5. Kyu $\mathrm{HH}$, Stein $\mathrm{CE}$, Pinto $\mathrm{CB}$, et al. Causes of death among children aged 5-14 years in the WHO European region: A systematic analysis for the Global Burden of
Disease Study 2016. Lancet Child Adolesc Health. 2018;2(5):321-337. https://doi. Disease Study 2016. Lancet Child Adoles
org/10.1016/S2352-4642(18)30095-6

6. Institute of Medicine (US) and National Research Council (US) National Cancer Policy Board. Childhood cancer survivorship: Improving care and quality of life [homepage on the Internet]. In Hewitt M, Weiner SL, Simone JV, editors. The epidemiology of childhood cancer. Washington, DC: National Academies Press, 2003 [cited 2020 July 22]; p. 2. Available from: https://www.ncbi.nlm.nih.gov/ books/NBK221740/

7. World Health Organisation. Children: reducing mortality [homepage on the Internet]. 2019 [cited 2020 Jul 22]. Available from: https://www.who.int/newsroom/fact-sheets/detail/children-reducing-mortality

8. Masquelier B, Hug L, Sharrow D, et al. Global, regional, and national mortality trends in older children and young adolescents (5-14 years) from 1990 to 2016 : An analysis of empirical data. Lancet Glob Health. 2018;6(10):e1087-e1099. https://doi.org/10.1016/S2214-109X(18)30353-X

9. Howard SC, Metzger ML, Wilimas JA, et al. Childhood cancer epidemiology in lowincome countries. Cancer. 2008;112(3):461-472. https://doi.org/10.1002/cncr.23205

10. Kaatsch P. Epidemiology of childhood cancer. Cancer Treat Rev. 2010;36(4):277-285. https://doi.org/10.1016/j.ctrv.2010.02.003

11. Statistics South Africa. Statistical release P0302. Mid-year population estimates 2020 [homepage on the Internet]. 2020 [2020 Jul 9]. Available from: http://www. statssa.gov.za/publications/P0302/P03022020.pdf
12. Stefan DC, Stones DK, Wainwright RD, et al. Childhood cancer incidence in South Africa, 1987-2007. SAMJ. 2015;105(11):939-947. https://doi.org/10.7196/SAMJ. 2015.v105i11.9780

13. Gatta G, Botta L, Rossi S, et al. Childhood cancer survival in Europe 1999-2007: Results of EUROCARE 5-a population-based study. Lancet Oncol. 2014;15(1):35-47. https://doi.org/10.1016/S1470-2045(13)70548-5

14. Stones DK, De Bruin GP, Esterhuizen TM, Stefan DC. Childhood cancer survival rates in two South African units. SAMJ. 2014;104(7):501-504. https://doi org/10.7196/SAMJ.7882

15. Ferman S, Santos Mde O, Ferreira JM, et al. Childhood cancer mortality trends in Brazil, 1979-2008. Clinics (Sau Paulo). 2013;68(2):219-224. https://doi. org/10.6061/clinic/2013(02)OA16

16. Statistics South Africa. Statistical release P0309.3. Mortality and causes of death in South Africa, 2016: Findings from death notification [homepage on the Internet]. 2019 [cited 2020 Jul 22] Available from: http://www.statssa.gov.za/ publications/P03093/P030932016.pdf

17. Steliarova-Foucher E, Stiller C, Lacour B, Kaatsch P. International classification of childhood cancer, third edition. Cancer. 2005;103(7):1457-1467. https://doi. org/10.1002/cncr.20910

18. World Health Organization. Child growth standards [homepage on the Internet]. [cited 2020 Jul 22]. Available from: https://www.who.int/ childgrowth/standards/en/

19. World Health Organization. Interim WHO clinical staging of HIV/AIDS and HIV/ AIDS case definitions for surveillance [homepage on the Internet]. African Region 2005 [cited 2020 Jul 22]. Available from: http://www.who.int/hiv/pub/guidelines/ clinicalstaging.pdf

20. Sala $A$, Rossi $E$, Antillon $F$, et al. Nutritional status at diagnosis is related to clinical outcomes in children and adolescents with cancer: A perspective from Central America. Eur J Cancer. 2012;48(2):243-252. https://doi.org/10.1016/j.ejca. 2011.06.006

21. CHOC. St Siluan's warning signs of childhood cancer [homepage on the Internet] [cited 2020 Oct 20]. Available from: https://choc.org.za/childhood-cancer-earlywarning-signs/

22. Tam D-T, Eduardo LF. Diagnosis delays in childhood cancer. Cancer 2007;110(4):703-713. https://doi.org/10.1002/cncr.22849

23. South African National HIV prevalence, incidence and behaviour survey, 2012 [homepage on the Internet]. Launch ed. Cape Town: HRSC Press; 2014 [cited 2019 Aug 20]. Available from: http://www.hsrc.ac.za/uploads/ pageContent/4565/SABSSM $\% 20$ IV\%20LEO $\% 20$ final.pdf

24. Yarchoan R, Uldrick TS. HIV-associated cancers and related diseases. N Engl J Med. 2018;378(11):1029-1041. https://doi.org/10.1056/NEJMra1615896

25. Peterson CC, Demanelis K, Rentschler K, et al. Childhood cancer incidence and survival in Thailand: A comprehensive population-based registry analysis, 1990-2011. Pediatr Blood Cancer. 2019;66(1):e27428. https://doi.org/10.1002/ pbc. 27428

26. De Oliveira MM, Silva DRME, Ramos FR, Curado MP. Children and adolescents cancer incidence, mortality and survival a population-based study in Midwest of Brazil. Cancer Epidemiol. 2020;68(10):101795. https://doi.org/10.1016/j. canep.2020.101795

27. Yang L, Fujimoto J. Childhood cancer mortality in Japan, 1980-2013. BMC Cancer 2015;15:446. https://doi.org/10.1186/s12885-015-1472-x

28. Public Health England. Childhood cancer statistics, England annual report 2018 [homepage on the Internet]. London: PHE Publications; 2018 [cited 2019 Aug 29] Available from: http://www.ncin.org.uk/publications/reports/

29. Phillips SM, Padgett LS, Leisenring WM, et al. Survivors of childhood cancer in the United States: Prevalence and burden of morbidity. Cancer Epidemiol Biomarkers Prev. 2015;24(4):653-663. https://doi.org/10.1158/1055-9965.EPI-14-1418

30. Stefan DC, Stones DK. The South African paediatric tumour registry -25 years of activity. SAMJ. 2012;102(7):605-606. https://doi.org/10.7196/SAMJ.5719 